\title{
SLC6A8 wt Allele
}

National Cancer Institute

\section{Source}

National Cancer Institute. SLC6A8 wt Allele. NCI Thesaurus. Code C153431.

Human SLC6A8 wild-type allele is located in the vicinity of Xq28 and is approximately $8 \mathrm{~kb}$ in length. This allele, which encodes sodium- and chloride-dependent creatine transporter 1 protein, is involved in muscle cell physiology and creatine/phosphocreatine transport. Alterations of the gene are associated with X-linked creatine deficiency syndrome. 